\title{
Comparing groundwater recharge and base flow in the Bukmoongol small-forested watershed, Korea
}

\author{
E A Combalicer ${ }^{1,2}, \mathrm{~S} \mathrm{H} \mathrm{LeE}^{3}, \mathrm{~S} \mathrm{AhN^{1 }}$, D Y Kim${ }^{1}$ and $\mathrm{S} \mathrm{IM}^{3, *}$ \\ ${ }^{1}$ Department of Forest Sciences, College of Agriculture and Life Sciences, Seoul National University, \\ San 56-1, Sillim-dong, Gwanak-gu, Seoul, 151-921, Korea. \\ ${ }^{2}$ College of Forestry, Nueva Vizcaya State University, 3700 Bayombong, Nueva Vizcaya, Philippines. \\ ${ }^{3}$ Department of Forest Sciences, Research Institute for Agriculture $\mathcal{E}$ Life Sciences, College of Agriculture and \\ Life Sciences, Seoul National University, San 56-1, Sillim-dong, Gwanak-gu, Seoul, 151-921, Korea. \\ *e-mail: junie@snu.ac.kr
}

\begin{abstract}
Groundwater recharge and base flow using different investigated methods are simulated in the 15-ha Bukmoongol small-forested watershed located at the southern part of Korea. The WHAT system, PART, RORA, PULSE, BFI, and RAP software are used to estimate groundwater recharge or base flow and base flow index from the measured streamflow. Results show that about 15-31 per cent of annual rainfall might be contributed for base flow. The watershed groundwater recharge proportions are computed to about 10-21 per cent during the wet period and 23-32 per cent for the remainder periods. Mean annual base flow indices vary from 0.25 to 0.76 estimated using different methods. However, the study found out that all methods were significantly correlated with each other. The similarity of various methods is expressed as a weighted relationship provided by the matrix product from the principal component analysis. Overall, the BFI and WHAT software appeared consistent in estimating recharge or base flow, and base flow index under Korea's conditions. The case study recommends the application of different models to other watersheds as well as in low-lying areas where most observation groundwater wells are located with available streamflow data.
\end{abstract}

\section{Introduction}

In recent years, scarcity of water has been widely recognized due to a growing population and its related purposes. Water in the watershed is basically imminent through runoff and streamflow. In some cases, the streamflow is seasonally available only on the basis of precipitation and is sometimes dependent on the adequacy of groundwater recharge behaviour. Groundwater recharge refers to the replenishment of an aquifer with water from the land surface which is usually expressed as an average rate of water per year, similar to precipitation (Sophocleous and Schloss 2000).

There is a great interest in understanding groundwater and surface water interactions as fundamental components in the water balance.
Forest hydrologists and watershed managers have often dealt with uncertainty in quantifying the amount of the base flow or recharge. A common recommendation in the literature is that recharge should be estimated from multiple methods and the results compared, but in reality, comparing the results may be difficult because of differences inherent in the methods (Risser et al 2005b). However, Delin and Risser (2007) perceived that the actual recharge rate is never known with 100 per cent certainty at a given location, use of multiple recharge and base flow estimation methods is beneficial.

The groundwater recharge can be estimated from the unsaturated-zone drainage (Wellings 1984), water budget (Bauer and Vaccaro 1987; Jyrkama et al 2002), water table fluctuation (Sophocleous 1991), and recession-curve

Keywords. Base flow separation; base flow index; groundwater recharge; WHAT. 
displacement (Rorabaugh 1960; Daniel 1976). In the same manner, base flow separation methods separate part of the streamflow hydrograph attributed to groundwater runoff. According to Rutledge (2005a), base flow is not a recharge. However, base flow is sometimes used as an approximation of recharge when underflow (the flow of ground water beneath and by passing a stream), evapotranspiration from riparian vegetation, and other losses of groundwater from the watershed are thought to be minimal. The major assumptions in using base flow for estimating recharge are that base flow equals groundwater discharge and that ground water discharge is approximately equal to recharge (Risser et al 2005a).

Groundwater estimation methods have been intensively reviewed and discussed in the literature (Lerner et al 1990; Rutledge 1998; Scanlon et al 2002; Moix and Galloway 2004; Bent 2005; Brodie and Hostetler 2005; Delin and Falteisek 2007; Coes et al 2007). In Korea, however, Park (1996) and Lee and Yoon (1996) used the base flow separation method while Moon et al (2004) utilized the water table fluctuation techniques to estimate the groundwater recharge ratio. Since early 1990s, there have been computer programs concerned with specific algorithms that had been developed to simulate the base flow or recharge of the watershed. Many studies utilized computer codes which provide acceptable results.

In this study, different software were used to compare the estimated recharge or base flow based on available streamflow records collected from the small-forested watershed in Korea. The methods involved have inherent differences derived from specific algorithms or equations which provide a logical sense in comparing result differences.

This study aimed to

- utilize the capability of the RORA, PULSE, PART, BFI, RAP, and WHAT system software in relation to recharge and base flow separation analyses,

- estimate the proportion of the base flow from streamflow and rainfall on the small-forested watershed,

- estimate the groundwater recharge and base flow from different methods, and

- determine the correlations and associations of the investigated methods.

\section{Materials and methods}

\subsection{Description of study area}

The study area is the Bukmoongol small-forested watershed located within $35^{\circ} 01^{\prime} 30^{\prime \prime}-35^{\circ} 03^{\prime} 00^{\prime \prime} \mathrm{N}$ latitude and $127^{\circ} 36^{\prime} 00-127^{\circ} 37^{\prime} 30^{\prime \prime} \mathrm{E}$ longitude in the southern part of Korea (figure 1). The total area of the watershed is about 15 hectares. The elevation ranges from 120-341 $\mathrm{m}$ above sea level with around $850 \mathrm{~m}$ stream length lying within the area. The watershed is dentritic in shape with compactness and drainage density coefficients of 0.86 and $56.8 \mathrm{~m} /$ ha, respectively.

The Bukmoongol watershed is fully vegetative consisting mostly of Pinus koraiensis and Pinus rigida tree species. The characteristics of the soil surface up to $1 \mathrm{~m}$ depth do not vary much in texture which is largely loam to clay loam. High soil organic matter features is prevalent in most parts of the area. The saturated hydraulic conductivity of the watershed was estimated at $15.32 \mathrm{~mm} / \mathrm{h}$.

The climate is classified as monsoon. The peak monthly temperature recorded was $-15.4^{\circ} \mathrm{C}$ in winter (January) and $34.9^{\circ} \mathrm{C}$ during summer (August). The average annual precipitation is $1374 \mathrm{~mm}$, most of which occurs during the warm summer season from June to August.

\subsection{Data collection}

Meteorological and hydrological parameters have been monitored in the area since 1991 using meteorological and water level gauging stations installed within the watershed. The meteorological station is located about $30 \mathrm{~m}$ away from the monitoring station. At present, there are three water level monitoring stations in the watershed. In the present case study, however, the analysis was concentrated in the Bukmoongul area because it has longer available streamflow data. Likewise, the entire watershed is homogenous in terms of vegetation, topography and soil characteristics.

The water level from rectangular sharp-crested weir was monitored using a gauge recorder and lately OTT Thalimedes with integral data logger. In particular, water level data were converted to an equivalent streamflow over the surface flow monitoring station from the period of 1992-1998. From streamflow data, base flow separation and recession analysis methods were conducted to characterize the base flow and recharge characteristics of the Bukmoongol small-forested watershed.

\subsection{Base flow estimation methods investigated}

The different methods for estimating recharge or base flow investigated in the study are summarized in table 1. Recharge was estimated on a daily, monthly and annual basis using Rorabaugh equations (Rorabaugh 1964; Rutledge 1998). Base flow was estimated using streamflow-hydrograph separation (Rutledge 2005a), digital filter algorithm 


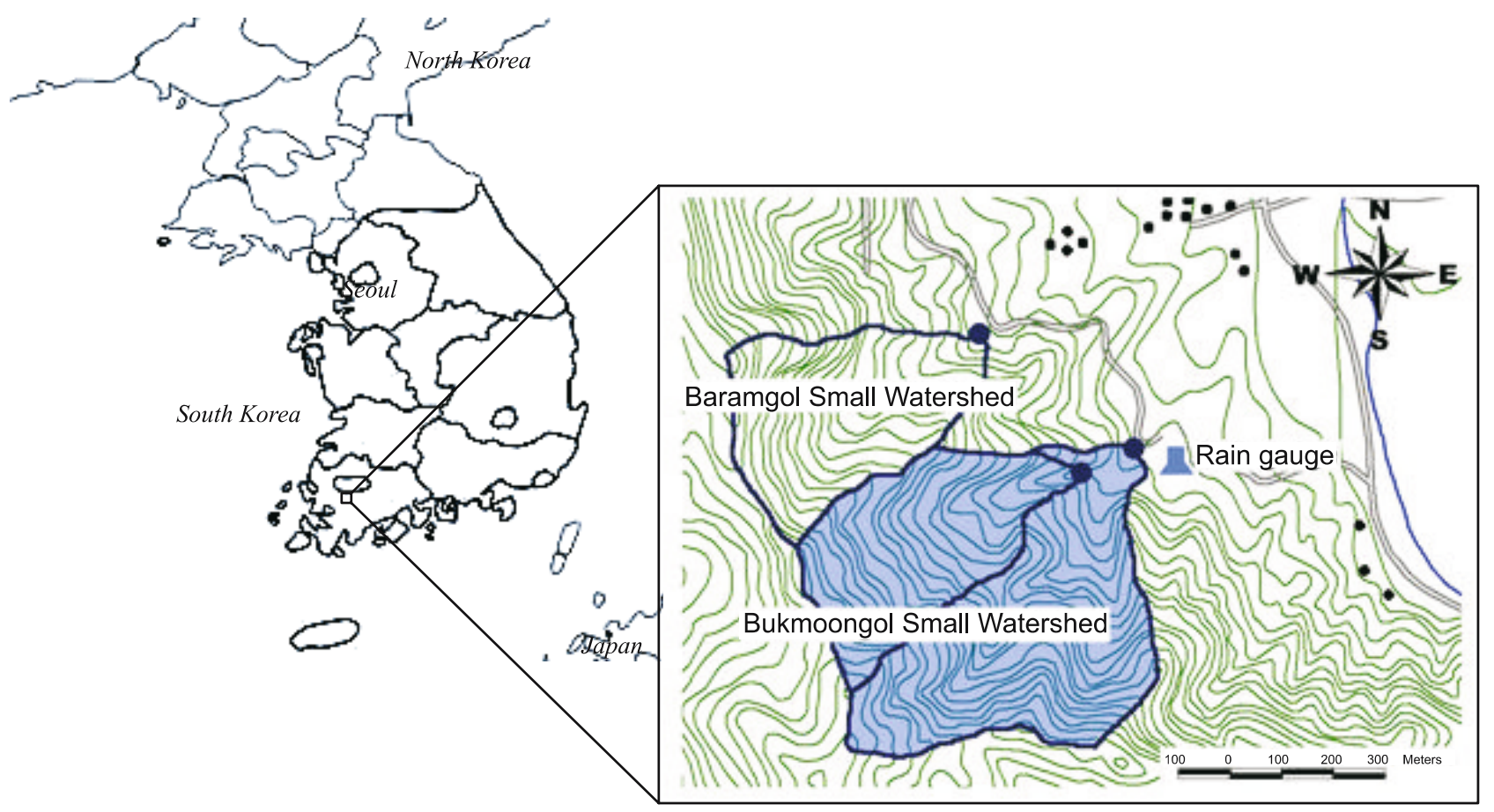

Figure 1. Location of the Bukmoongol watershed, Korea.

(Lyne and Hollick 1979; Marsh et al 2003), British Institute of Hydrology standard method (Wahl and Wahl 2001), modified method (Wahl and Wahl 2001), low minimum method (Lim et al 2004), and recursive digital filter method (Eckhardt 2005).

Six packages of software, namely: PART (Rutlegde 2007a), RORA (Rutlegde 2007b), PULSE (Rutlegde 2002), River Analysis Package (Marsh et al 2003), Base Flow Index (Wahl and Wahl 2001), and WHAT (Lim et al 2004) were used in the simulation of base flow or recharge estimates. Prior to the simulation of the recharge, RECESS program (Rutlegde 2005b) was used to determine the recession index and to define the master recession curve from the analysis of streamflow records.

\subsubsection{Recharge methods}

Two packages of software were considered in estimating the recharge of the watershed. Application of both RORA and PULSE requires an estimate of the slope of the streamflow-recession curve (recession constant) representing periods when all streamflow is from groundwater discharge. The recession constant was computed by constructing a master recession curve from the streamflow record using the RECESS program (Rutledge 1998). In this study, the computed median recession index for the forested watershed was 34.2 with 17 numbers of segments.

\subsubsection{RORA software}

The RORA software estimates groundwater recharge based on streamflow records. The RORA model, also known as the Rorabaugh Method (Rorabaugh 1960; Daniel 1976; Rutledge 2007b), estimates groundwater recharges for each streamflow peak using the recession-curve-displacement method. It is based on an analytical model that describes groundwater discharge subsequent to recharge to the water table (Rorabaugh 1964). The analytical model represents a cross section from the hydrologic divide to the stream where groundwater discharge occurs. The aquifer is conceptualized according to assumptions of uniform aquifer thickness, hydraulic conductivity, and storage coefficient. A detailed update on the use of the RORA software for recharge estimation was reported by Rutledge (2007b).

In the RORA model, the total recharge is calculated using the following equation:

$$
R=\frac{2\left(Q_{2}-Q_{1}\right) K}{2.3026}
$$

where $R=$ total volume of recharge, $Q_{1}=$ ground water discharge at critical time as extrapolated from the streamflow recession preceding the event, $Q_{2}=$ ground water discharge at critical time as 
Table 1. Summary of methods investigated for estimating recharge or base flow, and base flow index.

\begin{tabular}{|c|c|c|c|c|c|}
\hline Software & Method & $\begin{array}{l}\text { Quantity } \\
\text { estimated }\end{array}$ & Output & $\begin{array}{l}\text { Unit of } \\
\text { estimates* }\end{array}$ & Source \\
\hline \multicolumn{6}{|c|}{ Recharge methods } \\
\hline RORA & $\begin{array}{l}\text { Recession-curve- } \\
\text { displacement or } \\
\text { Rorabaugh approach }\end{array}$ & Recharge & Monthly, annual & in, $\mathrm{cfs}$ & $\begin{array}{l}\text { Rutledge } \\
\quad(2007 \mathrm{~b})\end{array}$ \\
\hline PULSE & $\begin{array}{l}\text { Trial and error } \\
\text { matching using } \\
\text { Rorabaugh approach }\end{array}$ & Recharge & $\begin{array}{l}\text { Daily, monthly, } \\
\text { annual }\end{array}$ & in, $\mathrm{cfs}$ & Rutledge (2002) \\
\hline \multicolumn{6}{|c|}{ Base flow methods } \\
\hline PART & $\begin{array}{l}\text { Hydrograph separa- } \\
\text { tion for base flow }\end{array}$ & $\begin{array}{l}\text { Base flow } \\
\text { Base flow index }\end{array}$ & $\begin{array}{l}\text { Daily, monthly, } \\
\text { annual }\end{array}$ & Per cent, in, cfs & $\begin{array}{r}\text { Rutledge } \\
\text { (2007a) }\end{array}$ \\
\hline RAP & $\begin{array}{l}\text { Lyn-Hollick digital } \\
\text { filtering separation }\end{array}$ & Base flow index & Annual & Per cent & $\begin{array}{l}\text { Marsh et al } \\
\quad(2003)\end{array}$ \\
\hline \multirow[t]{3}{*}{ WHAT System } & $\begin{array}{l}\text { Low minimum } \\
\text { method }\end{array}$ & $\begin{array}{l}\text { Base flow } \\
\text { Base flow index }\end{array}$ & $\begin{array}{l}\text { Daily, monthly, } \\
\text { annual }\end{array}$ & Per cent, cfs & Lim et al (2004) \\
\hline & $\begin{array}{l}\text { One parameter } \\
\text { method (Lyn-Hollick } \\
\text { filter approach) }\end{array}$ & $\begin{array}{l}\text { Base flow } \\
\text { Base flow index }\end{array}$ & $\begin{array}{l}\text { Daily, monthly, } \\
\text { annual }\end{array}$ & Per cent, cfs & Lim et al (2004) \\
\hline & $\begin{array}{l}\text { Recursive digital } \\
\text { filter } \\
\text { (Eckhardt digital } \\
\text { filter approach) }\end{array}$ & $\begin{array}{l}\text { Base flow } \\
\text { Base flow index }\end{array}$ & $\begin{array}{l}\text { Daily, monthly, } \\
\text { annual }\end{array}$ & Per cent, cfs & Lim et al (2004) \\
\hline \multirow[t]{2}{*}{ BFI } & Standard method & $\begin{array}{l}\text { Base flow } \\
\text { Base flow index }\end{array}$ & $\begin{array}{l}\text { Daily, monthly, } \\
\text { annual }\end{array}$ & $\begin{array}{r}\text { Acre-foot, } \\
\text { per cent }\end{array}$ & $\begin{array}{l}\text { Wahl and Wahl } \\
\text { (2001) }\end{array}$ \\
\hline & Modified method & $\begin{array}{l}\text { Base flow } \\
\text { Base flow index }\end{array}$ & $\begin{array}{l}\text { Daily, monthly, } \\
\text { annual }\end{array}$ & $\begin{array}{l}\text { Acre-foot, } \\
\text { per cent }\end{array}$ & $\begin{array}{l}\text { Wahl and Wahl } \\
\text { (2001) }\end{array}$ \\
\hline
\end{tabular}

${ }^{*}$ Units are converted into metric for analysis.

extrapolated from the streamflow recession following the event, and $K=$ recession index.

\subsubsection{PULSE software}

The PULSE software is intended for analyzing ground-water-flow system that is characterized by diffuse areal recharge to the water table and groundwater discharge to a stream. The use of the program can be appropriate if all or most groundwater in the basin discharges to the stream and if a streamflow-gauging station at the downstream end of the basin measures all or most outflow (Rutledge 1998, 2002). The assumptions required for applicability of the PULSE are similar to those of the RORA.

The model is applicable to a groundwater flow system that is driven by a really uniform recharge to the water table, and in which the groundwater discharges to a gaining stream. One of the two formulations used by the model allows for an instantaneous recharge pulse and subsequent groundwater discharge to the stream. The other formulation, which allows for a gradual hydrologic gain or loss term in addition to the instantaneous pulse, can be used to simulate the effects of gradual recharge to the water table and groundwater evapotranspiration or downward leakage to a deeper aquifer (USGS 2007).

Rutledge (2002) provided the brief explanation of the mathematical model used in the PUSLE computer program. Depending on modelinput information designated by the program user, the model uses one of two equations to calculate groundwater discharge over time. The first equation describes groundwater discharge after an instantaneous recharge amount:

$$
Q=\frac{1.866 A R_{i}}{K} \cdot \sum_{m=1,3,5}^{\infty} e^{\left(-0.933 m^{2} \pi^{2} r\right) /(4 K)}
$$

where $Q$ is total basin groundwater discharge, $A$ is basin drainage area, $R_{i}$ is instantaneous recharge depth, $K$ is recession index, and $t$ is time elapsed after the instantaneous recharge.

The second equation describes groundwater discharge caused by an instantaneous recharge amount followed by a gradual recharge rate: 


$$
\begin{aligned}
Q= & R_{g} A+2 R_{g} A \cdot \sum_{m=1,3,5}^{\infty}\left[\frac{0.933 R_{i}}{R_{g} K}-\frac{4}{\pi^{2} m^{2}}\right] \\
& \times e^{\left(-0.933 m^{2} \pi^{2} t\right) /(4 K)}
\end{aligned}
$$

where $R_{g}$ is the gradual recharge rate. Equation (3) can be used to simulate the effect of gradual recharge in the absence of instantaneous recharge by specifying $R_{i}$ to be zero. Gradual recharge will begin at $t=$ zero and will continue infinitely.

\subsubsection{Base flow methods}

Four different packages of software were used to provide estimates of base flow in the Bukmoongol small-forested watershed. Base flow is the part of streamflow usually attributed to groundwater discharge. In the streamflow-hydrograph separation method, base flow is used as proxy for recharge (USGS 2007).

\subsubsection{PART software}

The PART software, which is supported by the USGS, has been widely used to compute base flow (Rutledge and Mesko 1996; Holtschlag 1997; Nelms et al 1997; Bachman et al 1998). The PART was derived from the principle of partitioning streamflow to estimate a daily record of base flow (groundwater discharge) under the streamflow record. It separates base flow by equating streamflow to base flow on those days after a storm, meeting a requirement of antecedent-recession length greater than $N$ and rate of recession less than 0.1 log cycle per day and uses linear interpolation to connect across periods that do not meet those tests. $N$ is the approximate duration of surface runoff from Linsley et al (1982) as expressed below.

$$
N=(A)^{0.2},
$$

where $N$ is the time after which surface runoff ceases, in days; and $A$ is the watershed area, in square miles.

A detailed description of the algorithm used and operation of PART is provided in the user manual (Rutledge 2005a).

\subsubsection{BFI software}

The Base Flow Index (BFI) software was developed to make the base flow separation process less tedious and more consistent. The program implements a deterministic procedure developed by the British Institute of Hydrology standard method (BFI-SM) and modified method (BFIMM). The methods combine a local minimums analysis with a recession slope test. The program estimates the annual base flow volume of rivers and streams and computes an annual base flow index for multiple years of data. The two methods differ only in the test they use to identify turning points $(f)$ on the base flow hydrograph. Both separation methods begin by partitioning the year into $N$-day periods and determining the minimum flow within each period (Wahl and Wahl 2001).

A 5-day increment and a factor of 0.9 for the test to identify base flow turning points were used in the studied forested watershed. Selections of increments are influenced by the size of the drainage area and were determined based upon methods described by Wahl and Wahl (2001). Minimums in one location were compared to adjacent minimums to determine turning points on the base-flow hydrograph. The area beneath the hydrograph is the estimate of the volume of base flow for the period. For the Bukmoongol watershed, the slope change occurs at $N=5$ days. This was consistent with the observation that direct runoff generally ceases within 1-5 days following a storm. The program produces a table of base flow, total streamflow, and base-flow index for each water year, as well as summary statistics.

\subsubsection{RAP software}

The River Analysis Package (RAP) software was used in estimating the average annual base flow index. It contains the Time Series Analysis (TSA) module to help river managers, scientists and consultants to tackle a range of river management projects (Marsh et al 2003). TSA analyses use daily time series data (e.g., flow data) to generate summary statistics or to plot changes in statistics through time. It can be used for comparing alternate flow regimes, identifying changes in a flow regime through time and for generating flow statistics that can be used to predict the likely biological response to flow change. The program was developed with a graphical user interface that allows users to interactively investigate time series data. However, the program seemed not capable for measurement of daily and monthly base flow rate.

The Lyn-Hollick filter equation in calculating the base flow component of the hydrograph in RAP software is shown below. It has an alpha value of 0.975 .

$$
q_{f(i)}=\alpha \cdot q_{f(i-1)}+\left(q_{(i)}-q_{(i-1)}\right) 1+\frac{\alpha}{2}
$$


where $q_{(i)}$ is the original streamflow for the $i$ th sampling instant, $q_{f(i)}$ is the filtered quickflow for the $i$ th sampling instant, $q_{(i-1)}$ is the original streamflow for the previous sampling instant to $I, q_{f(i-1)}$ is the filtered quickflow for the previous sampling instant to $i$, and $\alpha$ is the filter parameter.

\subsubsection{WHAT system}

The Web-based Hydrograph Analysis Tool (WHAT) system is an online based computation of the base flow from streamflow data. The latest version of the WHAT system was developed with three base flow separation modules, namely: the local minimum, one parameter digital filter (Lyne and Hollick 1979; Arnold and Allen 1999; Eckhardt 2005; Lim et al 2005), and the recursive digital filter methods (Eckhardt 2005). Each method in the WHAT system has a distinctive feature. Further details regarding formulations and applications of the program are described by Lim et al (2005).

Theoretically, the WHAT Local Minimum Method (WHAT-LMM) searches the hydrograph for the minimum streamflow during an interval $(2 N \times$ days $)$. The Local Minimum Method simply connects the local minimum points by comparing the slope of hydrograph. However, the Local Minimum Method in the current WHAT system does not consider duration of direct runoff (Lim et al 2005).

The WHAT One Parameter Method (WHATOPM) is analogous to Base flow (BFLOW) filter and used the Lyne and Hollick (1979) approach as presented in equation (5). In the present study, a filter parameter of 0.925 was used.

The WHAT Recursive Digital Filter (WHATRDF), also known as Eckhardt filter method, requires a filter parameter and BFImax (maximum value of long term ratio of base flow to total streamflow) values. The digital filter method has been used in signal analysis and processing to separate high frequency signals from low frequency signals (Lyne and Hollick 1979). This method has been used in base flow separation since high frequency waves can be associated with direct runoff, and low frequency waves can be associated with base flow (Eckhardt 2005; Lim et al 2005). Thus, filtering direct runoff from base flow is similar to signal analysis and processing (Eckhardt 2005; Lim et al 2005).

Eckhardt (2005) digital filter is expressed as follows:

$$
\begin{gathered}
\left(1-B F I_{\max }\right) \cdot \alpha+b_{t-1} \\
b_{t}=\frac{+1(1-\alpha) \cdot B F I_{\max } \cdot Q_{t}}{1-\alpha \cdot B F I_{\max }},
\end{gathered}
$$

where $b_{t}$ is the filtered base flow at the $t$ time step, $b_{t-1}$ is the filtered base flow at the $t-1$ time step, $B F I_{\max }$ is the maximum value of the long term ratio of base flow to total streamflow, $\alpha$ is the filter parameter, and $Q_{t}$ is the total streamflow at the $t$ time step.

In the study area, the suggested values of 0.98 for filter parameter and 0.80 for $B F I_{\max }$ for a perennial stream with porous aquifer were used in the base flow separation computation.

\subsection{Data analysis}

The recharge and base flow rates generated by the different simulation models were analysed to determine correlations between methods or programs using bivariate correlations. In addition to the Kendall's tau correlation, the multivariate analysis, called principal component analysis (PCA) was also used on the dataset. The Kendall test was also chosen for correlation analysis because it measures the association between the original pairs of data points which are insensitive to the effect of outliers. The statistical package SPSS 16.0 for Window ${ }^{\circledR}$ was used for calculations.

The data reduction factor analysis (FA) extraction method using principal component analysis was applied to the datasets. PCA has been used for reduction of variables and clustering samples (Suk and Lee 1999; Thyne et al 2004; Lee et al 2008). In this study, PCA was used for the evaluation of the large ground water recharge or base flow values generated from different models. It is a multivariate statistical procedure that is commonly used to reveal patterns in a large dataset (Wold 1987; Winter et al 1998; Stetzenbach et al 1999). The central idea of PCA was to reduce the dimensionality of a dataset that consists of a large number of interrelated variables, while retaining as much of the variation that was present in the data set as possible. This was achieved by transforming the variables into a new set of variables, the principal components (PCs), which are uncorrelated, and which are ordered so that the first few retain most of the variation present in all of the original variables (Moon et al 2004).

In this case study, factors were estimated from principal component methods. The number of factors, called principal components (PCs), were defined according to the criterion that only factors that account for variances greater than 1 (eigenvalue - one criterion) should be included. The rationale for this criterion is that any component should account for more variance than any single variable in the standardized test score space. 


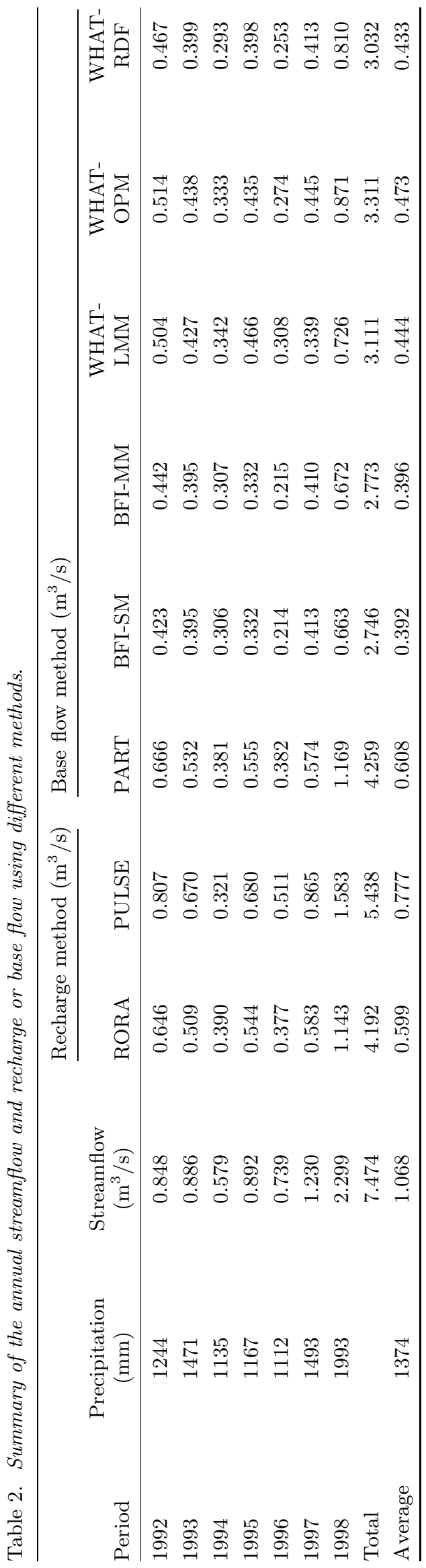

Although the factor matrix obtained in the extraction phase indicates the relationship between the factors and the individual variables, it is usually difficult to identify meaningful factors based on this matrix. Interpretation of the matrix may be easier using the rotation procedure. Rotation does not affect goodness of fit of a factor solution. That is, although the factor matrix changes, the commonalities and the percentage of total variance explained do not change. The rotation process in FA allows flexibility by presenting a multiplicity of views of the same dataset (Dillon and Goldstein 1984; Andrade et al 2008). Varimax with Kaiser normalization, which is frequently applied to increase the participation of the variables with higher contribution and reduce those with lesser contributions, was adopted in this study. Thus, PCAs were subjected to raw varimax rotation.

\section{Results and discussion}

\subsection{Base flow or recharge simulation}

To facilitate the comparison of the different methods, the annual recharge and/or base flow rates associated with the available annual historical streamflow records were predicted as shown in table 2. In the Bukmoongol small-forested watershed, the results of the simulation using different methods varied annually depending on the available streamflow, where the recharge methods gave reasonably higher estimates than the base flow separation approaches. The average annual streamflow was $1.068 \mathrm{~m}^{3} / \mathrm{s}$ and the predicted recharge values ranged from 0.608 to $0.777 \mathrm{~m}^{3} / \mathrm{s}$ while the base flow estimates ranged from 0.392 to $0.559 \mathrm{~m}^{3} / \mathrm{s}$.

Estimates in PULSE and RORA software appeared favourably higher than remaining methods. High values derived from PULSE and RORA software conformed to the basic premise of the Rorabaugh approach that recharge events occurred concurrently with peaks in streamflow (Rutledge 1998). In addition, the formulation of the Rorabaugh equation showed that the total potential groundwater discharge to the stream at critical time after a peak in streamflow was equal to the approximately one-half of the total volume of water that recharged the groundwater system during the peak (Rutledge 1998). In such case, a large amount of recharge estimates were mostly accumulated during the rising limb of the entire streamflow hydrograph (figure 2). It should be noted that the streamflow in the watershed occurred largely from June to August. In contrast, the BFI standard and modified methods were continually producing lower estimated values because of the simplifying assumptions inherent in 


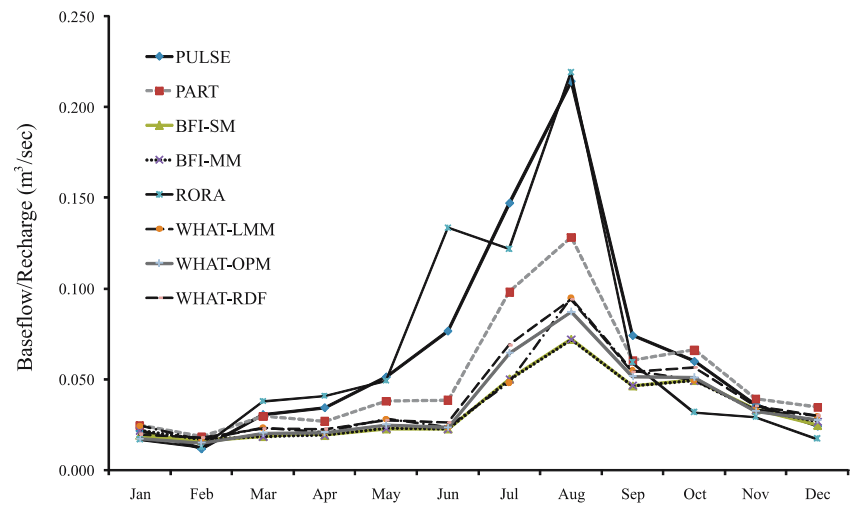

Figure 2. Average monthly estimated recharge or baseflow in the Bukmoongol watershed.

Table 3. Ratio of the recharge or base flow from the precipitation in different methods for the forested watershed.

\begin{tabular}{lccc}
\hline & & \multicolumn{2}{c}{ Seasonal condition } \\
\cline { 3 - 4 } $\begin{array}{l}\text { Methods } \\
\text { investigated }\end{array}$ & Annual & $\begin{array}{c}\text { Wet } \\
\text { (summer) }\end{array}$ & $\begin{array}{c}\text { Dry } \\
\text { (fall, winter } \\
\text { and spring) }\end{array}$ \\
\hline PUSLE & 31 & 30 & 32 \\
PART & 24 & 19 & 31 \\
BFI-SM & 15 & 10 & 23 \\
BFI-MM & 16 & 10 & 24 \\
RORA & 31 & 34 & 28 \\
WHAT-LMM & 18 & 12 & 26 \\
WHAT-OPM & 18 & 13 & 24 \\
WHAT-RDF & 19 & 14 & 27 \\
Average & 21 & 18 & 27 \\
\hline
\end{tabular}

the equation particularly the collection of 5-day minimum flows, which did not really represent the direct runoff conditions in the watershed. However, the discrepancy of estimates in other methods investigated was merely evident during high flows. The outcomes clearly demonstrated that recharge or base flow rates varied annually relying on the precipitation and streamflow availability. Overall, the results revealed that the higher the streamflows, the higher the expected base flows.

The rate of precipitation greatly influenced the streamflow and recharge estimates in the watershed. Table 3 shows the recharge ratio computed from the precipitation at a given period. The mean recharge or base flow ratio is the ratio of the mean recharge or base flow to the mean precipitation as a percentage. In this study, mean annual recharge and base flow rates ranged from 15-31 per cent of precipitation and averaged 21 per cent of precipitation from different methods investigated. Low recharge proportions were computed ranging from 10-21 per cent in all methods involved during the summer. Under this condition, the recharge and precipitation rates were both higher and that resulted in a low proportion. However, low recharge and precipitation amounts occurred during the dry period when much of the rainfall is directly absorbed in soils.

Results for the RORA, PULSE and PART software were reasonably comparable to other studies. Risser et al (2005a) found apparent recharge ratio for the RORA (33 per cent of the precipitation) and PULSE (24 per cent of the precipitation) in the small watershed in Spring Creek at Milesburg. In the eastern United States, Risser et al (2005b) applied the same approach which the RORA recharge rates estimated about 3338 per cent of the precipitation, 25-29 per cent of the precipitation for PART, and 24 per cent of the precipitation using PULSE. Likewise, Delin and Falteisek (2007) simulated RORA recharge rates ranged from 8 per cent to 44 per cent of precipitation from 38 basins in Minnesota, USA.

In South Korea's river basins, Moon et al (2004) found a range from 6.6-10 per cent using the water table fluctuation method during the Korean monsoon season. Park (1996) established a range from 7.7-12 per cent ground water ratio using base flow separation with data for both dry and rainy days. Lee and Yoon (1996) found a range from 5.1-7.9 per cent during dry season. Results of the estimated ground water recharge ratio were moderately higher with those from previous studies. It is important to note that this study was conducted in the small forested watershed. From different methods, the BFI and WHAT system simulated proportion appeared close to the reported range under this particular condition. However, variations of recharge can relate from factors such as watershed size, vegetation influence, precipitation duration, evapotranspiration rates, and temperature which affect the groundwater behaviours.

The performance of different software varied seasonally in this watershed. Figure 2 shows the average monthly recharge or base flow estimates ranged from $0.012 \mathrm{~m}^{3} / \mathrm{s}$ to $0.219 \mathrm{~m}^{3} / \mathrm{s}$ for all methods. As expected, recharge values were greatest in the summer, which typically included as much as 75 per cent of total annual recharge of the watershed. A much smaller recharge and base flow values usually occurred in winter and fall seasons. Highest values $\left(0.219 \mathrm{~m}^{3} / \mathrm{s}\right)$ were generated by the RORA software. Other methods such as PULSE, PART, WHAT-LMM, WHAT-RDF, WHAT-OPM, BFI-SM, and BFI-MM obtained also the peak monthly recharge or base flow values during summer season with $0.214,0.128,0.095$, $0.094,0.087,0.071$, and $0.072 \mathrm{~m}^{3} / \mathrm{s}$, respectively.

Results clearly showed that the simulated recharge rates were consistently higher than the base flow methods. Similarly, the WHAT system 


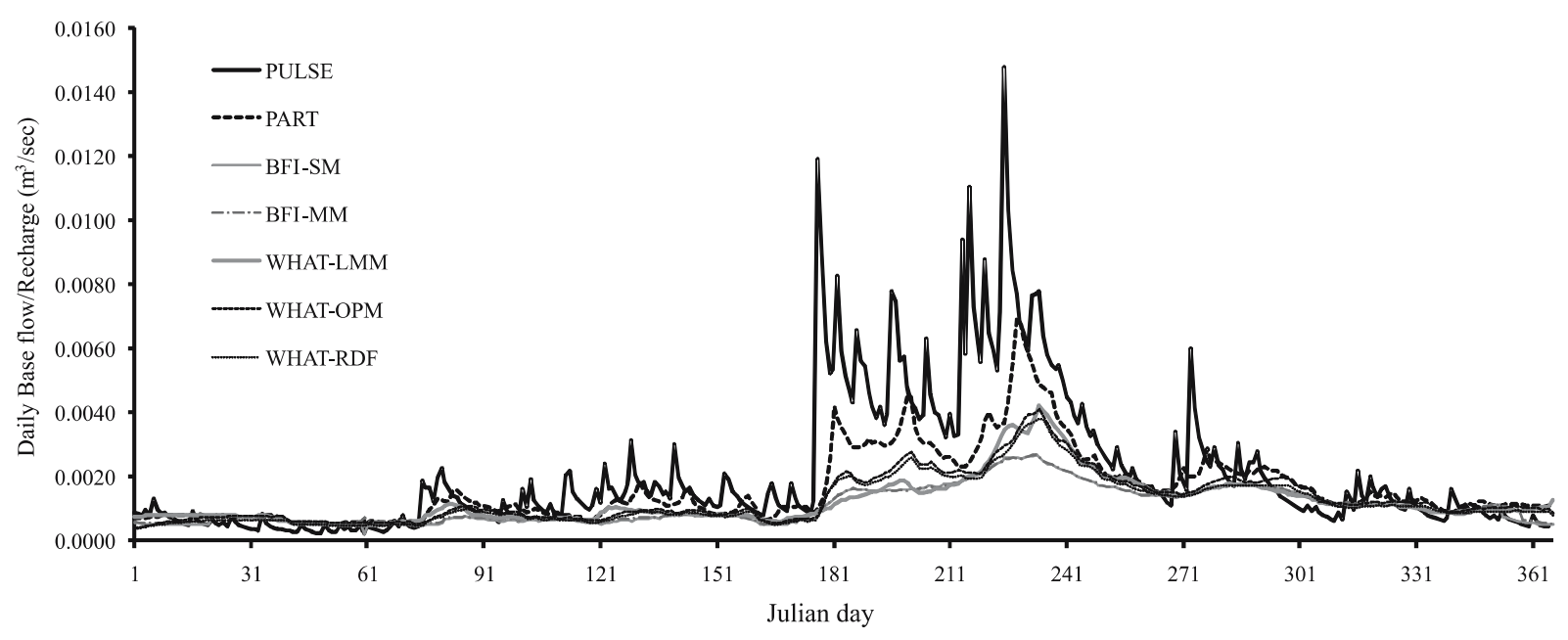

Figure 3. Average daily base flow or recharge of the Bukmoongol small-forested watershed.

and BFI roughly demonstrated the same pattern in response to the seasonal variation. However, the result of RORA simulation displayed that the estimated recharge rate was almost the same with the mean streamflow in the month of June. The result is surprising because the RORA data were similar to other models input. This inconsistency could be confused for groundwater discharge by the RORA method. Halford and Mayer (2000) and Rutledge (2000) referred to some factors such as slow drainage to streams from bank storage, wetlands, surface-water bodies, soils, and snowmelt runoff that can exceed groundwater discharge during recession periods. Rutledge (2007b) suggested that the minimum time scale for reporting program results might be the quarter year but notes that there are applications in which results can be reported on a smaller time scale such as the month. Moreover, Risser et al (2005b) pointed out that the RORA and PULSE are not hydrograph separation techniques although they are using streamflow data to estimate groundwater recharge.

On the basis of daily recharge or base flow, the recharge method using PULSE software obtained high estimates than the base flow methods (figure 4). The RORA model was excluded in the analysis on a daily basis. The RORA does not estimate continuous or daily ground water discharge under the streamflow hydrograph (Risser et al 2005b; Rutlegde 2007b). As a result, three modules of WHAT and two methods of BFI software exhibited the same pattern of estimates responding to changes in streamflow input. Daily estimates from PART and PULSE programs dominate higher estimates than other base flow methods. Overall, mean daily recharge or base flow rates ranged from $0.0003-0.0099 \mathrm{~m}^{3} / \mathrm{s}$ in the watershed.

Different methods seem to have their own limitations, uncertainties, applications and advantages as

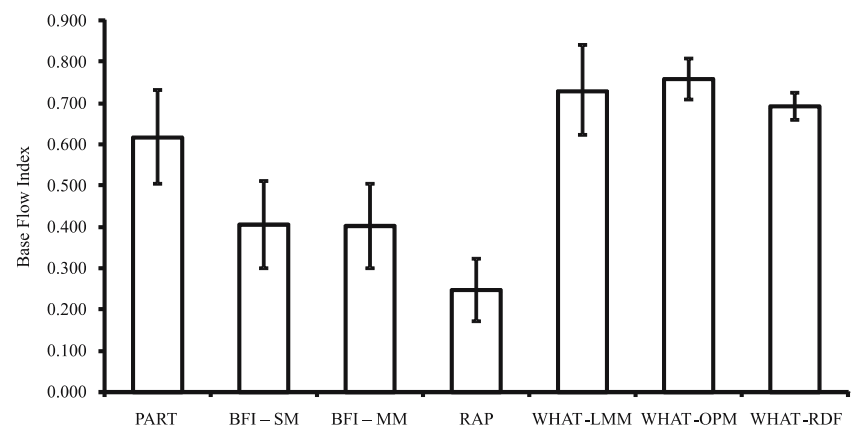

Figure 4. Average and standard deviation of the base flow index using different methods at the Bukmoongol small-forested watershed.

manifested in results of this study. As far as application is concerned, the WHAT system appeared the easiest method in separating the base flow from the streamflow. The software has a great advantage compared to other methods in which local flow data are allowed to enter to the WHAT server and select appropriate filter parameter values for a watershed. Direct runoff and base flow output values are provided in tabular format as well as a graphical hydrograph. This capability provides an efficient base flow estimation using local datasets to a certain location.

\subsection{Base flow index estimates}

Base flow index is described as the average rate of base flow relative to the average rate of the total flow and varies from zero to one where increasing values indicate an increasing contribution of base flow to streamflow. The case study determined the base flow index for a seven-year period in the Bukmoongol watershed using seven different algorithms (figure 4). The computed mean annual indices ranged from 0.246 to 0.756 , 
which indicated as much as 24 to 75 per cent of the total flow attributed to the base flow. Results exhibited that the WHAT-OPM method obtained higher average estimates (0.756) than WHAT-LMM (0.730), WHAT-RDF (0.691), PART (0.617), BFI-SM (0.404), BFI-MM (0.401), and RAP (0.246). The low index indicated a less percentage of direct surface runoff in the watershed. The higher proportion of base flow may also be associated to the present stable conditions of the forested watershed. In addition, the disparity of an annual index to base flow for each program attributed from the total streamflow or runoff, filter method values, precipitation, and hydrological and hydrogeological characteristics of the watershed.

Limited studies have been mentioned using a certain program for the base flow index. For instance, Moix and Galloway (2004) found a range from 0.28-0.33 base flow index at the Buffalo River in northern Arkansas using BFI software. Likewise, Neff et al (2005) reported 0.70 average index using the PART model in the Greak Lakes basin in Canada. Lim et al (2005) for their part observed that the base flow separated using a local minimum method was typically overestimated than base flow values obtained using the digital filter methods when multiple high peaks occur in a short time period.

Findings from the software mentioned above are really comparable to the simulated values in this study. The BFI software demonstrated for a low base flow index simulation while the PART can generate a high index depending on the total streamflow discharge. Results also revealed that the RAP and WHAT-OPM models gave different base flow index values even though both methods utilized the Lyn-Hollick filter approach. The discrepancy in the estimates can be attributed to the different filter parameter values used in each particular program. In essence, an increase in filter parameter value will result in a decrease in base flow index and vice versa.

From the standpoint of prediction stability, the WHAT-RDF method gave the most stable results over the seven-year period as indicated by the least value of standard deviation $(s=0.034)$, indicating that the annual predicted values are more uniform as compared to the other methods (figure 4). On the other extreme, the PART method gave the least stable results as indicated by the computed $s=0.114$ which is the highest among the seven methods evaluated. Ideally, since the different methods were used to predict base flow under identical watershed conditions within each year, the yearly fluctuations of the predicted base flows of each method, as represented by the standard deviation, should be minimal. Methods with the least base flow prediction fluctuations can thus be considered as more superior over those with larger fluctuations when prediction stability is the prime consideration for selection of method.

\subsection{Comparison of different methods}

The scatter plot matrix describing the relationship between the predicted recharge or base flows predicted by the methods evaluated is presented in figure 5. Results show moderate to very high positive association between the predicted base flows of any pair of methods. The test of hypothesis also revealed significant (Pearson) correlation between any pair of prediction methods. Moderate correlations were noted in RORA paired with the other methods except PULSE and PART, where high correlations were obtained. On the other hand, very high correlations were obtained in WHATRDF paired with any of the other methods, again, with the exception of RORA. The Kendall's Tau $\left(\tau_{b}\right)$ coefficient was also considered because the test is relatively insensitive to the presence of individual outliers. Under this test, all methods also demonstrated positive association to each other.

The correlation between all possible pairs of methods was statistically significant for a twotailed test at the 0.01 level. The situation was expected because of the line of reasoning that the higher streamflow, the higher base flow that can be predicted. It must be pointed out that the base flow or recharge predictions by the different models were based from a common set of streamflow data. The results implied that the significant relationships between the different methods investigated simply indicate that the trends or the fluctuations of the base flow predicted by the different methods are similar and conforms to the trend of the streamflow. Consequently, the correlation coefficient cannot fully explain the accuracy of predictions of any particular method.

\subsection{Principal component analysis}

The validity of test applications was performed to recharge and base flow data prior to the factor reduction analysis. The test parameter used for the analysis was the Kaiser-Meyer-Olkin (KMO) measure of sampling adequacy and Bartlett's test of sphericity. The value was 1839.289 with a significance level of 0.0001 , indicating that factor analysis could be applied to the groundwater recharge and base flow data. In particular, the KMO value was closer to 1 , it indicated that the factor analysis becomes more significant (Kaiser 1974). The $\mathrm{KMO}>0.5$ is acceptable (Andradea et al 2008) while KMO values greater than 0.8 are generally accepted as significant (Moon et al 2004). In this 


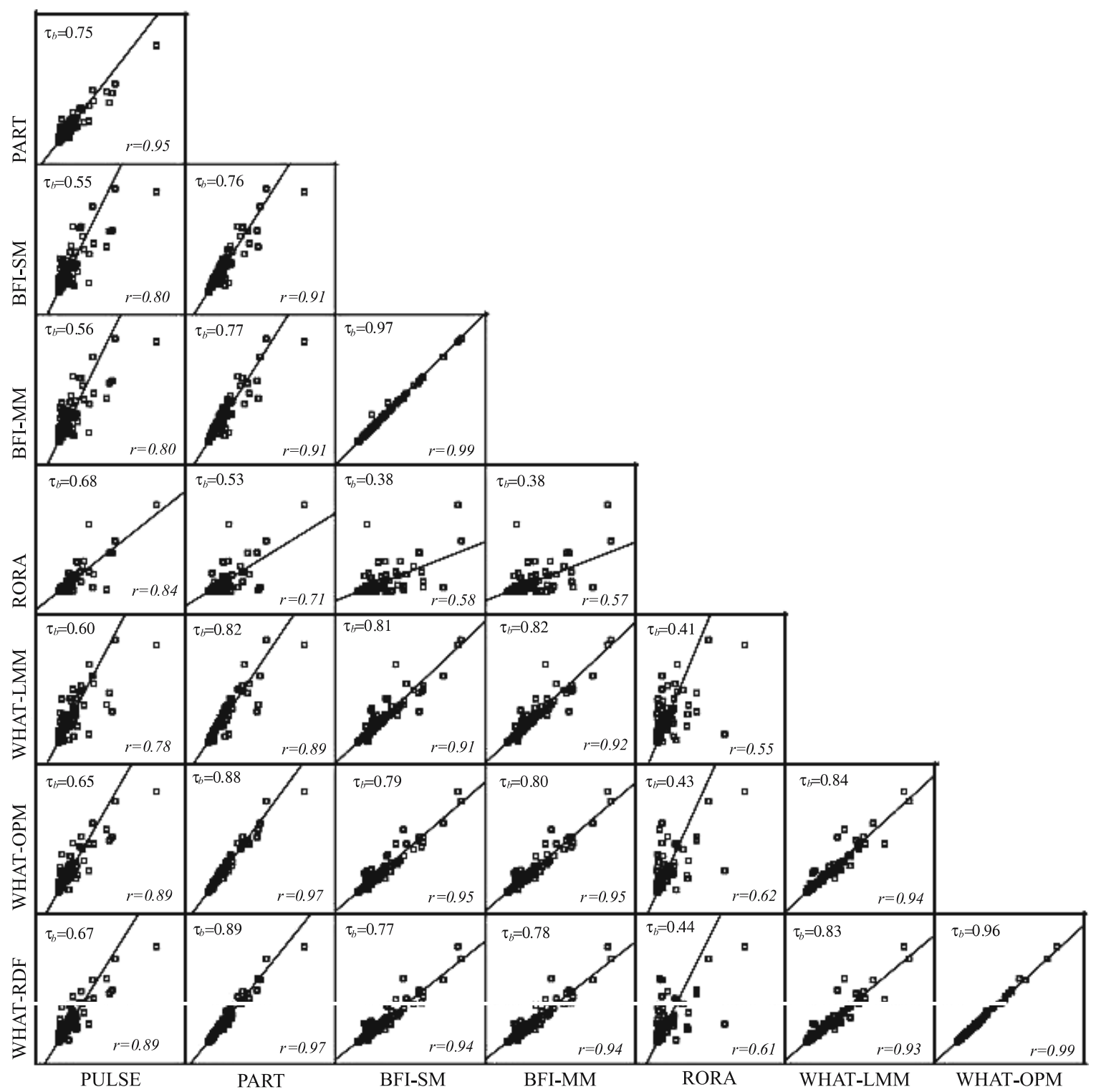

Figure 5. Scatter plot matrix examining the relationship among recharge or base flow methods.

study, the KMO value was 0.834 , implying that PCA can achieve a significant reduction of the dimensionality of the original dataset.

Principal component loadings can be visualized as a measure of the association between the groundwater recharge or base flow models and each PC. Factor analysis of the recharge and base flow data produced two PCs with a 96.2 per cent total variance explained. In this case study, a 95 per cent was considered as cut-off. As a result, the similarity is expressed as a weighted relationship provided by the matrix product as shown in figure 6 . The loading of the recharge for the WHAT-OPM method (0.987) was the highest onto component 1 , that of the RORA method (0.665) onto component 2 . In addition, the RORA, PULSE, and WHAT-LMM models in component 1 found moderately low loading and communalities, while remaining models are high. The overlap between models obtained with negative and positive loadings in component 2. Mostly, models with the highest loadings make the largest contribution. In this forested watershed, PC 1, which explains 87.4 per cent of the variance, is highly and positively driven by all methods under investigations. These high loadings can be explained by the similarity of the fluctuation pattern under the condition in the forested watershed. PC 2 ( $8.8 \%$ of the variance) is mainly driven by PULSE, PART and RORA, which may be attributed to software that provide high estimates recharge during the wet season.

To reduce the overlap of original variables over each principal component, a varimax rotation was conducted. Usually, varimax rotation allows a better and more explicit assignment of experimental variables to $\mathrm{FA} / \mathrm{PCAs}$, since the correlations 


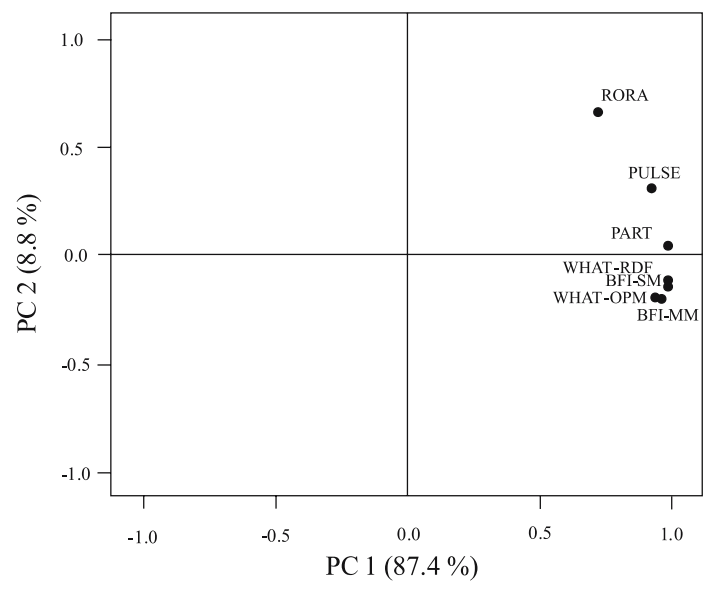

Figure 6. Component plot of factors 1 and 2 of different recharge and base flow methods for the forested watershed.

Table 4. First two principal rotated component matrix loadings for eight groundwater recharge and base flow methods.

\begin{tabular}{lcc}
\hline & \multicolumn{2}{c}{ Component loadings } \\
\cline { 2 - 3 } Methods & 1 & 2 \\
\hline PULSE & 0.622 & 0.755 \\
PART & 0.812 & 0.556 \\
BFI-SM & 0.922 & 0.329 \\
BFI-MM & 0.926 & 0.322 \\
RORA & 0.267 & 0.945 \\
WHAT-LMM & 0.906 & 0.314 \\
WHAT-OPM & 0.902 & 0.418 \\
WHAT-RDF & 0.896 & 0.420 \\
Eigenvalues & 5.26 & 2.43 \\
\% of Variance & 65.8 & 30.4 \\
\hline
\end{tabular}

Extraction method: Principal component analysis. Rotation method: Varimax with Kaiser normalization.

between some of the variables and components are high, others are low, and few correlations are intermediate (Helena et al 2000; Singh et al 2005; Andradea et al 2008). The intermediate loadings indicate some relationship between the component and variables (models input), but its real significance is difficult to assess (Andradea et al 2008). Models input loadings and variance explained in the watershed after varimax rotation is presented in table 4 . For a study site, the total variance is better spread out among the two rotated components (RCs). RC 1 explains 65.8 per cent of total variance and signifies strong positive loadings on the PART, BFI-SM, BFI-MM, WHATLMM, WHAT-RDF, and WHAT-OPM, moderate loading on the PULSE, and intermediate loading on the RORA. RC 2 is strongly contributed by the RORA, moderate loading on the PULSE, and intermediate loading on the PART, BFI-SM,
BFI-MM, WHAT-LMM, WHAT-RDF, and the WHAT-OPM methods. In consequence, no overlap has been found and also conformed to the positive correlation of all models.

\section{Conclusions}

Groundwater recharge or base flow is a fundamental component in the water balance in a watershed. In this study, multiple indirect methods were utilized to estimate the recharge or base flow from the available seven-year streamflow data at the Bukmoongol small-forested watershed in Korea. Six types of software with a total of eight modules were used to compare the recharge or base flow as well as base flow index. Different methods expressed their own capabilities, limitations, and uncertainties. In particular, the RORA program does not estimate continuous or daily groundwater discharge under the streamflow hydrograph. The PULSE for its part was not designed to analyze long periods of record. Likewise, the RAP was just capable on the basis of the mean base flow index estimation.

The correlation and principal component analysis demonstrated that the recharge or base flow estimates are comparable and associated to each other. However, recharge methods (PULSE and RORA) provided moderate correlation and always greatest estimates especially during the high streamflow fluctuation in the summer season while other methods are consistently on the same pattern. Different observations were noticed in the base flow index simulation where WHAT system constantly generated higher indices.

Based on the results of the simulation, the study generally came up to an observation that the BFI and WHAT appeared consistent in estimating recharge or base flow, and base flow index of the study site. These programs gave reasonable results which were closely comparable to the previous groundwater recharge ratio studies under Korea's conditions. As a result, groundwater recharge and base flow methods not only considered the streamflow data but also parameter filter values and identified days of negligible surface runoff which basically offered more reliable estimates. Of the methods used in this study, the WHAT methods are the simplest and easiest to apply prediction stability. Overall, the WHATRDF method gave the most stable results over other models.

The use of multiple recharge and base flow estimation methods is beneficial particularly in the forest areas which seems to lack appropriate instruments to monitor the groundwater flow. The study recommends the application of different models to other watersheds in Korea and compared results 
to the present case study. The same recommendation is addressed in the low-lying areas where most observation groundwater wells are located with available streamflow data.

\section{Acknowledgment}

This study was conducted with the support of "Forest Science and Technology Projects (Project No. S210607L0110304)" provided by Korea Forest Service.

\section{References}

Andradea E M, Araújo H, Palácio Q, Souzab I H, Leão R A and Guerreiro M J 2008 Land use effects in groundwater composition of an alluvial aquifer (Trussu River, Brazil) by multivariate techniques; Environ. Res. 106 170-177.

Arnold J G and Allen P M 1999 Validation of automated methods for estimating baseflow and groundwater recharge from stream flow records; J. Am. Water Res. Assoc. 35(2) 411-424.

Bachman J L, Lindsey B D, Brakebill J W and Powars D S 1998 Ground-water discharge and base-flow nitrate loads of nontidal streams, and their relation to a hydrogeomorphic classification of the Chesapeake Bay Watershed, middle Atlantic Coast; USGS Water-resources Investigations Report 98-4059, 71p.

Bauer H H and Vaccaro J J 1997 Documentation of a deep percolation model for estimating ground-water recharge; USGS open-file report 86-536, 180p.

Bent G C 2005 Streamflow, ground-water recharge and discharge, and characteristics of surficial deposits in Buzzards Bay Basin, Southeastern Massachusetts; USGS Water-resources Investigations Report 95-4234, 61p.

Brodie R S and Hostetler J J 2005 A review of techniques for analysing baseflow from stream hydrographs; www.connectedwater.gov.au/documents/IAH05_ Baseflow.pdf (January 08, 2008).

Coes A L, Spruill T B and Thomasson M J 2007 Comparison of recharge rates estimated from multiple methods for a shallow unconfined aquifer; J. Hydrol. 15(4) 773-788.

Daniel J F 1976 Estimating groundwater evapotranspiration from streamflow records; Water Resour. Res. 123 360-364

Delin G N and Risser D W 2007 Ground-water recharge in humid areas of the United States - a summary of ground-water resources program studies, 2003-06; USGS fact sheet $f_{s}-2007-3007,4 \mathrm{p}$.

Delin G N and Falteisek J D 2007 Ground-water recharge in Minnesota; USGS fact sheet 2007-3002, 4p.

Dillon W R and Goldstein M 1984 Multivariate analysis methods and applications; Wiley New York, 587p.

Eckhardt K 2005 How to construct recursive digital filters for baseflow separation; Hydrol. Processes 19(2) $507-515$.

Jyrkama M I, Sykes J F and Normani S D 2002 Recharge estimation for transient ground water modelling; Ground Water 40(6) 638-648.

Halford K J and Mayer G C 2000 Problems associated with estimating ground water discharge and recharge from streamflow-discharge records; Ground Water $\mathbf{3 8 ( 3 )}$ $331-342$
Helena B, Pardo R, Vega M, Barrado E, Fernandez J M and Fernandez L 2000 Temporal evolution of groundwater composition in an alluvial aquifer (Pisuerga River, Spain) by principal component analysis; Water Res. 34(3) 807-816.

Holtschlag D J 1997 A generalized estimate of ground-water recharge rates in the Lower Peninsula of Michigan; USGS Water Supply Paper 2437, 37p.

Kaiser H F 1974 Index of factorial simplicity; Psychometrika 39 31-36.

Lerner D N, Issar A S and Simmers I 1990 Groundwater recharge: a guide to understanding and estimating natural recharge; International Association of Hydrogeologists, International Contributions to Hydrogeology $\mathbf{8}$ $147 \mathrm{p}$.

Lee D R and Yoon Y N 1996 Estimation and analysis of groundwater recharge in Korea; Journal of Korean Society of Civil Engineering 16(II-4) 321-334.

Lee J, Ko K S, Kim J M and Chang H W 2008 Multivariate statistical analysis of underground gas storage caverns on groundwater chemistry in Korea; Hydrol. Process. (in press).

Lim K J, Engel B A, Tang Z, Choi J, Kim K S, Muthukrishnan S and Tripathy D 2004 WHAT: Webbased Hydrograph Analysis Tool; http://cobweb.ecn. purdue.edu/ what/ (August 08, 2007).

Lim K J, Engel B A, Tang Z, Choi J, Kim K S, Muthukrishnan S and Tripathy D 2005 Automated web GIS based hydrograph analysis tool, WHAT; J. Am. Water Res. Assoc. 41(6) 1407-1416.

Lyne V and Hollick M 1979 Stochastic time-variable rainfall-runoff modelling; Institute of Engineers Australia National Conference 89-93.

Linsley R K, Kohler M A and Paulhus J L H 1982 Hydrology for Engineers; McGraw-Hill, New York.

Marsh N A, Stewardson M J and Kennard M J 2003 River Analysis Package; http://www.toolkit.net.au/ (February 8, 2007).

Moix M W and Galloway J M 2004 Base flow, water quality, and streamflow gain and loss of the Buffalo River, Arkansas, and selected tributaries, July and August 2003; USGS Scientific Investigations Report 2004-5274.

Neff B P, Day S M, Piggott A R and Fuller L M 2005 Base flow in the Great Lakes Basin; USGS Scientific Investigations Report 2005-521\%.

Nelms D L, Harlow G E and Hayes D C 1997 Baseflow characteristics of streams in the Valley and Ridge, the Blue Ridge, and the Piedmont Physiographic Provinces of Virginia; USGS Water Supply Paper 2457, 48p.

Moon S K, Woo N C and Lee K S 2004 Statistical analysis of hydrographs and water-table fluctuation to estimate groundwater recharge; J. Hydrol. 292 198-209.

Park C K 1996 Estimation of the available amount of groundwater in South Korea: application of five major river basins; J. Korean Soc. Groundwater Env. 3 $21-26$.

Risser D W, Conger R W, Ulrich J E and Asmussen M P 2005a Estimates of ground water recharge based on streamflow-hydrograph methods - Pennsylvania; USGS Open-file Report 2005-1333, 30p.

Risser D W, Gburek W J and Folmar G J 2005b Comparison of methods for estimating ground-water recharge and base flow at a small watershed underlain by fractured bedrock in the eastern United States; USGS Scientific Investigations Report 2005-5038, 31p.

Rorabaugh M I 1960 Use of water levels in estimating aquifer constants in a finite aquifer; International Association of Scientific Hydrology 52 314-323. 
Rorabaugh M I 1964 Estimating changes in bank storage and ground-water contribution to streamflow; International Association of Scientific Hydrology 63 432-441.

Rutledge A T and Mesko T O 1996 Estimated hydrologic characteristics of shallow aquifer systems in the Valley and Ridge, the Blue Ridge, and the Piedmont Physiographic Provinces based on analysis of streamflow recession and base flow; USGS Professional Paper 1422-B, $58 \mathrm{p}$.

Rutledge A T 1998 Computer programs for describing the recession of ground-water discharge and for estimating mean ground-water recharge and discharge from streamflow records - Update; USGS Water-resources Investigations Report 98-4148, 51p.

Rutledge A T 2000 Considerations for use of the RORA program to estimate ground water recharge from streamflow records; USGS Open-file Report 00-156.

Rutledge A T 2002 User guide for PULSE program; http://water.usgs.gov/ogw/pulse/ (January 30, 2007).

Rutledge A T 2005a Program user guide for PART; http://water.usgs.gov/ogw/recess/UserManualPART. pdf (January 30, 2007).

Rutledge A T 2005b Program user guide for RECESS; http://water.usgs.gov/ogw/recess/UserManualRECESS. pdf (January 30, 2007).

Rutledge A T 2007a Program user guide for PART; http://water.usgs.gov/ogw/part/UserManualPART.pdf (January 30, 2007).

Rutledge A T 2007b Update on the use of the RORA program for recharge estimation; Ground Water 45(3) $374-382$.

Scanlon B R, Healy R W and Cook P G 2002 Choosing appropriate techniques for quantifying groundwater recharge; Hydrogeol. J. 10 18-39.

Singh K P, Malik A and Sinha S 2005 Water quality assessment and apportionment of pollution sources of Gomti river (India) using multivariate statistical techniques - a case study; Anal. Chim. Acta 538(2) 355-374.

Sophocleous M A 1991 Combining the soil water balance and water-level fluctuation methods to estimate natural ground-water recharge: practical aspects; J. Hydrol. 124 229-241.

Sophocleous M A and Schloss J A 2000 Estimated annual ground water recharge; http:// www.kgs.ku.edu/HighPlains/atlas/atrch.htm (January 08, 2008).

Suk H and Lee K K 1999 Characterization of a groundwater hydrochemical system through multivariate statistical analysis: clustering into groundwater zones; Ground Water 37 358-366.

Stetzenbach K J, Farnham I M, Hodge V F and Johannesson K H 1999 Using multivariate statistical analysis of groundwater major cation and trace element concentrations to evaluate groundwater flow in a regional aquifer; Hydrol. Process. 13 2655-2673.

Thyne G, Gler C and Poeter E 2004 Sequential analysis of hydrochemical data for watershed characterization; Ground Water 42 711-723.

USGS 2007 PULSE: Model-estimated ground-water recharge and hydrograph of ground-water discharge to a stream; http://water.usgs.gov/ogw/pulse/ (January 30, 2007).

Wahl T L and Wahl K L 2001 BFI - a computer program for computing an index to base flow; http:// www.usbr.gov/wrrl/twahl/bfi.html (February 5, 2007).

Wellings J R 1984 Recharge of the upper chalk aquifer at a site in Hampshire, England; J. Hydrol. 69 259-273.

Winter T C, Harvey J W, Franke O L and Alley W M 1998 Ground water and surface water - a single resource; USGS Circular 1139, 79p.

Wold S 1987 Principal component analysis; Chemomet. Intell. Lab. Systems 2 27-52. 